\title{
comem \\ Comprehensive Understanding the Disaster-Causing Mechanism, Governance Dilemma and Targeted Countermeasures of Urban Pluvial Flooding in China
}

\author{
Feng Kong $1,2, * \mathbb{C}$, Shao Sun ${ }^{3, *} \mathbb{( D )}$ and Yifei Wang ${ }^{4, *}$ \\ 1 College of Humanities and Development Studies, China Agricultural University, Beijing 100083, China \\ 2 Center for Crisis Management Research, Tsinghua University, Beijing 100084, China \\ 3 National Climate Center, China Meteorological Administration, Beijing 100081, China \\ 4 Training Center, China Meteorological Administration, Beijing 100081, China \\ * Correspondence: kongfeng0824@cau.edu.cn (F.K.); sunshao@cma.gov.cn (S.S.); guipu616@163.com (Y.W.)
}

check for

updates

Citation: Kong, F.; Sun, S.; Wang, Y. Comprehensive Understanding the Disaster-Causing Mechanism,

Governance Dilemma and Targeted Countermeasures of Urban Pluvial Flooding in China. Water 2021, 13, 1762. https://doi.org/10.3390/ w13131762

Academic Editor:

Martina Zeleňáková

Received: 19 May 2021

Accepted: 24 June 2021

Published: 25 June 2021

Publisher's Note: MDPI stays neutral with regard to jurisdictional claims in published maps and institutional affiliations.

Copyright: (C) 2021 by the authors. Licensee MDPI, Basel, Switzerland. This article is an open access article distributed under the terms and conditions of the Creative Commons Attribution (CC BY) license (https:/ / creativecommons.org/licenses/by/ $4.0 /)$.

\begin{abstract}
Urban pluvial flooding in China has become one of the major challenges for sustainable development. This paper analyzes the impact of climate change, urbanization, and integrated disaster drivers on urban pluvial flooding hazards, starting from the disaster-causing mechanisms of urban pluvial flooding in China. This paper then analyzes the main features and progress of urban pluvial flooding governance in China. In particular, this paper describes the progress of sponge cities in China. On the basis of the above contents, this paper describes three manifestations of the fragmentation dilemma at the level of governance, namely, fragmentation in value integration due to conflicting management orders and service values, fragmentation in resource and power allocation due to the lack of vertical top-level design and blurred horizontal departmental management boundaries, and fragmentation in policy formulation and implementation due to outdated urban flood control standards and interdepartmental information compartmentalization. In response to the fragmentation dilemma in urban pluvial flooding management in China, this paper introduces the concept of holistic governance and clarifies the path of urban waterlogging management, i.e., forming a collaborative and diversified governance subjects, deeply optimizing the organizational structure of urban waterlogging management, creating a mature information-based governance platform, and improving the legal and rule of law construction model. This paper is informative for understanding the governance of urban pluvial flooding in China from a government-led management level.
\end{abstract}

Keywords: China; urban heat island; urban rain island; urban pluvial flooding; pluvial flooding causal mechanisms; urbanization; urban pluvial flooding governance

\section{Introduction}

In recent decades, under the joint influence of global climate change and rapid urbanization, the water cycle process and elements have undergone drastic changes, extreme weather events have increased and enhanced [1-3], urban heat island effect and urban rain island effect have emerged [1,2], urban surface runoff and confluence mechanisms have changed, which makes the urban pluvial flooding disasters increasingly serious [4-6].

World Meteorological Organization statistics show that from 1970 to 2009, there were 7870 hydro-meteorological-related disasters worldwide, causing a total number of 1.86 million deaths and USD 1.90 trillion in economic losses, of which rainstorms and floods accounted for $79 \%$ of the total number of disasters, with $56 \%$ of the deaths and $85 \%$ of the economic losses, respectively [7]. The increase in the frequency and severity of urban pluvial flooding disasters has posed a huge challenge to sustainable development and economic construction in countries around the world [8-11].

China is significantly influenced by monsoon, and urban pluvial flooding is concentrated from May to September $[7,10]$. Since the rapid development of urbanization after the 
implementation of China's reform and opening-up policy in 1978, urban pluvial flooding disasters are more serious, and the phenomena of "urban sea-viewing" have occurred repeatedly in major cities in China, especially in the eastern coastal cities [12]. Statistics from the China Water and Drought Disaster Bulletin 2018 show that from 2000 to 2018, China suffered 21,720 deaths and direct economic losses of RMB 316.39 billion due to urban pluvial flooding [13]. Among them, on 18 July 2007, Jinan City was hit by a extremely heavy rainstorm, causing more than 30 deaths and 170 injuries, about 330,000 people affected, and the city's direct economic loss was about RMB 1.32 billion [13]. On 21 July 2012, Beijing City and its surrounding areas were hit by the heaviest rainstorm and pluvial flooding in 61 years, resulting in 79 deaths, 1.62 million people affected, and economic losses of 11.64 billion [14]. On 11 April 2019, influenced by the convergence of cold and warm air currents, Shenzhen City experienced short-lived rainstorm and sudden pluvial flooding in several areas of the city, resulting in 11 deaths [15]. In 2020, severe pluvial flooding caused by rainstorm that lasted for many days in southern China, according to the Ministry of Emergency Management of the People's Republic of China website, as of 10 July 2020, pluvial flooding caused 33.85 million people affected in 27 provinces, 141 people died, and the direct economic loss was RMB 69.59 billion $[13,16]$.

Urban pluvial flooding has become a prominent problem affecting the public safety of cities in China and an important factor limiting the economic and social development of China [16-18]. A scientific and systematic understanding of the disaster-causing mechanism of urban pluvial flooding and a comprehensive understanding of the dilemma in urban pluvial flooding governance are the basis and core of improving the urban pluvial flooding governance system, improving urban storm flooding prevention and mitigation capacity, and reducing urban pluvial flooding disasters losses [19-22].

In China, the governance of urban pluvial flooding involves several government departments, including the Urban Management Committee, Meteorological Bureau, Water Resources Department, Housing and Construction Department, Transportation Department, Development and Reform Commission, Emergency Management Department, etc. All of these departments are administrative functions of a city, and perform all related functions under the direction of city decision makers [23]. Among them, the Urban Management Committee is mainly responsible for studying the planning, plans, overall programs and major policy measures for urban environment design and urban management [24]. The Meteorological Bureau is mainly responsible for monitoring and forecasting of urban rainstorms and early warnings. The Water Resources Department is mainly responsible for water resources planning, river and lake basin planning, pluvial flooding control planning, and participates in the preparation of drainage planning and implementation [25]. The Housing and Construction Department is mainly responsible for urban housing construction and renovation and other works [26]. The Transportation Department is mainly responsible for urban transportation development planning and construction work. The Development and Reform Commission is mainly responsible for the coordination of economic and social development [27]. The Emergency Management Department is responsible for the public emergencies among themselves, including emergency relief work for urban pluvial flooding events. Since urban pluvial flooding affects all aspects of urban development, all the above-mentioned departments have some administrative functions in urban pluvial flooding governance, and their administrative functions are largely independent of each other in China [25].

What are the local and general characteristics of the disaster-causing mechanism of urban pluvial flooding in China in the context of climate change and urbanization? How is urban pluvial flooding in China affected by both climate change and urbanization, and what are the characteristics of their disaster-causing mechanisms on urban pluvial flooding? From a disaster system perspective, how the interactions between the disaster-formative environments, the hazards and the exposures drive the formation and intensification of urban pluvial flooding? Based on the understanding of the mechanism of urban pluvial flooding, what are the current dilemmas encountered in urban pluvial flooding governance 
in China? How are we to understand the dilemmas in urban pluvial flooding governance from the perspective of administrative management? How are we to solve the these dilemmas in urban pluvial flooding governance? These issues are both the focus of attention in the current urban pluvial flooding governance in China by the scientific and practical communities, and are also the core issues that this paper tries to explore.

Based on the above-mentioned problems, this paper tries to explain the disastercausing mechanism of urban pluvial flooding in China, especially from the perspectives of climate change, urbanization impact and disaster system. On this basis, this paper analyzes the main features and progress of urban pluvial flooding governance in China and the fragmentation dilemma of value integration, the fragmentation dilemma of resource and power allocation, and the fragmentation dilemma of policy formulation and implementation in urban pluvial flooding governance, aiming to reflect the governance dilemmas in terms of conflicting management orders and service values, lack of vertical top-level design at national level and blurred horizontal departmental management boundaries, outdated urban pluvial flooding control standards, and information barriers and information silos in urban pluvial flooding governance. Finally, from the perspective of holistic governance, this paper tries to conclude that holistic governance can effectively cope with the above dilemmas and propose practical paths for holistic governance of urban pluvial flooding (Figure 1). The above-mentioned contents are set to help global audiences effectively understand urban pluvial flooding governance in China.

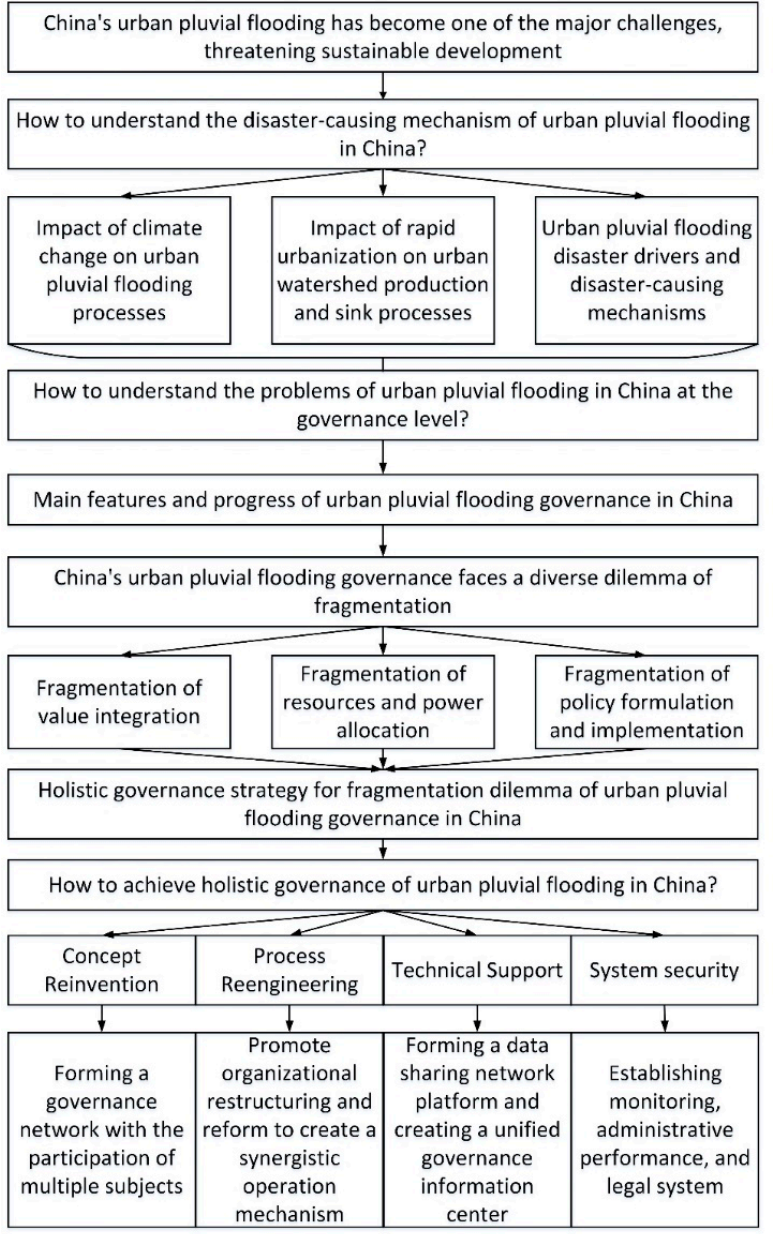

Figure 1. Logical framework of disaster-causing mechanism, main features and progress, governance dilemma and holistic governance of urban pluvial flooding in China. 


\section{Comprehensive Understanding of the Disaster-Causing Mechanism of Urban Pluvial Flooding in China \\ 2.1. Impact of Climate Change on Urban Pluvial Flooding Processes in China}

Climate change with global warming as the main symptom is an indisputable fact [1-3]. Additionally, climate change and its attendant consequences are considered to be one of the most important challenges facing humanity today $[1,28]$. The Intergovernmental Panel on Climate Change Fifth Assessment Report points out that global climate change is due to the increased concentration of greenhouse gases caused by global warming, and that climate change poses a great challenge to the sustainable development and use of global and regional water resources [1,29-32].

Climate change brings changes in many environmental elements, both in urban areas and in other regions [33]. As social, cultural, and technical centers, urban areas attract more and more people, making them more sensitive and vulnerable in the face of natural disasters [34].

According to the 2006-2018 China Water and Drought Disaster Bulletin statistics [13], China has been flooded in more than 100 cities every year since 2006, including 258 cities flooded in 2010, 184 in 2012, and 234 in 2013. According to the special research on 351 cities by the Ministry of Housing and Urban-Rural Development of the People's Republic of China [15], 62\% of the cities in China had pluvial flooding from 2008 to 2010, 137 had pluvial flooding more than 3 times, and 57 of them had the maximum flooding time more than $12 \mathrm{~h}$. Rainstorm is the most direct driver of urban pluvial flooding [6,16], and climate change is directly responsible for global and regional changes in rainstorm.

The Intergovernmental Panel on Climate Change Fifth Assessment Report [1] indicates that climate change will lead to a continued increase in the frequency and intensity of extreme weather events around the world. Many studies have analyzed the spatial and temporal evolution characteristics and causes of global and regional rainstorm under changing environments. For example, Trenberth [35] shows that global land surface rainfall has increased by $2 \%$ since the beginning of the 20th century; Konapala et al. [36] divide the globe into nine regions based on precipitation characteristics and analyze the characteristics of precipitation and evapotranspiration changes in the nine global regions, showing that four of the nine global regions show an increase in precipitation changes, while the remaining five regions show a decrease in evapotranspiration changes accompanied by an increase in average precipitation and evapotranspiration; The results of Schuster et al. [37] show that the frequency and magnitude of intense precipitation events in the Midwestern region of the U.S. are increasing due to climate change.

Many scholars have analyzed the spatial and temporal evolution characteristics of extreme precipitation or rainstorm in China and the causes of the changes $[6,7,33,38-40]$. Studies have shown that the rainstorm events in the North China Plain are more random during the past few decades $[10,15,16]$, with the maximum rainfall historically occurring much higher than the common heavy rainfall in the North China Plain [17].

For coastal cities, rainstorm, high tide level and typhoon are the main driving factors of pluvial flooding, specifically when rainstorm occurs in the region, the tide level in the estuary is unpredictable [19]. When high tide level occurs, the rainstorm generated in the region is complex and diverse, and the occurrence of typhoon may form a compound urban pluvial flooding disaster of wind, storm and tide [34], while the sea level rise due to global warming will intensify the frequency and extent of pluvial flooding events in coastal cities [19].

Global warming will not only have a direct impact on the global hydrological cycle, but will also exacerbate the urban heat island effect, whereby urban areas exhibit higher atmospheric and surface temperatures compared to rural areas [34,35,41,42]. At present, the urban heat island effect has attracted widespread attention around the world, and studies have shown that regional hydro-climatic conditions have a mutual influence on the urban heat island effect [41,42], and further in-depth research work is needed to investigate the effect of the urban heat island effect on the regional hydrological cycle $[2,15,16]$. 


\subsection{Impact of Rapid Urbanization on Urban Watershed Runoff and Confluence Processes in China}

Urbanization is a common phenomenon in China and around the world [14]. Along with the rapid urbanization process, the number of urban population is growing rapidly. According to statistics, $56.2 \%$ of the world's population live in urban areas in 2020 , and the number of urban populations is projected to continue to grow, with nearly $67 \%$ of the world's population expected to live in urban areas in 2050 [13]. The increase in impervious area will lead to reduce of infiltration in urban areas, and the decrease in vegetation will also lead to the weakening of the evapotranspiration process, thus leading to the increase in surface flow in urban areas [41,42]. At the same time, the original rough surface is replaced by a relatively smooth artificial impermeable surface, which inevitably leads to an acceleration of the time of concentration and re-establishes an urban pluvial flooding process line with high peak runoff and early peak occurrence under the same storm conditions [16].

Under the same rainstorm conditions, the urban pluvial flooding process with high peak runoff and early peak present time is formed [3]. Currently, many studies have been conducted on the hydrological effects of urbanization with the help of hydrodynamic models, and it is generally agreed that the expansion of urbanization increases the runoff and peak pluvial flooding flows in urban watersheds, exacerbates the degree of urban flooding, and reduces the base flow in urban watersheds and the interactive processes of groundwater and surface water in the surrounding urban areas [41-45].

In addition, the increase in anthropogenic heat emission in urban areas, the decrease in evaporative cooling process, the increase in urban surface roughness and the topographic features of urban areas will often intensify the urban heat island effect, and the urban heat island effect may have some influence on the hydrological cycle [2]. The urban heat island effect may have some influence on the hydrological cycle and affect the rainstorm characteristics of urban areas, especially the frequency and intensity of extreme rainstorms in urban areas may increase, thus causing the urban rain island effect $[1,3]$. This is mainly because the rapid development of urbanization has forced the thermal properties of the city's subsurface to change, resulting in the thermal airflow slowly gathering over the city and accumulating thicker thermal airflow, coupled with the increase in condensation nodules and dust over the city, resulting in significantly higher temperatures in the city than in the suburbs and forming the heat island effect [3]. As a direct consequence, the air layer in the city is extremely unstable, which can easily lead to increased convection movements up and down the air [16,43]. If the increasing heat island effect of urban development is concentrated in the rainy season, more water vapor and condensation nuclei and convection conditions will easily lead to a large area of prolonged rainstorm, forming the rain island effect $[1,2]$.

\subsection{Urban Pluvial Flooding Disaster Drivers and Disaster-Causing Mechanism in China}

The main reasons for the intensification of urban pluvial flooding in a changing environment can be analyzed in terms of changes in the hazards, changes in the disasterformative environments, and changes in the vulnerability of urban exposures to flooding [34]. Firstly, climate change and urbanization are the most important drivers of urban pluvial flooding, which mainly exacerbate the intensity of the hazards [5,41,42].

Secondly, the change of disaster-formative environments is mainly due to the development of housing, transportation, commerce and industry in urban areas, which leads to a wide shrinkage of permeable surface and water area in urban areas, resulting in a serious reduction of water storage capacity and urban drainage capacity in urban areas, thus aggravating the risk of urban pluvial flooding. Micro-topography, such as concave overpasses in urban areas, are very easy to form water under rainstorm conditions, which will also aggravate the risk of urban pluvial flooding [19]. At the same time, unreasonable urban planning and construction can also aggravate the degree of urban pluvial flooding. Due to unreasonable urban planning and construction, a large number of ponds, fish ponds and even lakes in urban areas have been filled in, some rivers and ditches have been 
filled in or transformed, and the water storage capacity and overflow capacity of urban watersheds have been greatly reduced, thus increasing the risk of urban pluvial flooding.

Thirdly, the change in the exposures of urban areas is mainly reflected in the development of urbanization, which has changed the original connectivity of many surface water bodies, such as rivers, lakes and reservoirs, as well as the transformation path of surface water and groundwater [16]. Most natural river and lake drainage channels have been replaced by urban drainage networks. Additionally, most natural water cycles have become artificial water cycles composed of many hydraulic structures, which has led to a huge change in the path of urban water cycles. Additionally, drainage networks and natural rivers and lakes are often not reasonably connected, exacerbating the vulnerability of urban drainage carriers [44-48]. In addition, the design standard of the drainage system cannot meet the drainage needs of the city, the design standard of the pipe network system is low, and the standard of urban river management does not converge with urban development, which will also aggravate the vulnerability of urban drainage carriers $[16,47,48]$.

\section{Main Features and Progress of Urban Pluvial Flooding Governance in China}

\subsection{Strategies for Coping with Urban Pluvial Flooding}

The key measure to deal with urban pluvial flooding is to develop adaptive technologies for urban stormwater management $[16,23]$. The core of the different technologies that share the same approach is to increase surface infiltration, reduce runoff and the various impacts they produce [19]. Internationally, many developed countries have proposed and developed urban stormwater management measures and formed urban stormwater management systems with regional characteristics [45-49]. Although the names and focus directions of the systems vary from region to region, their core concepts are basically the same, i.e., stormwater source control and recycling and its multifunctional storage [27,50-52]. Among them, stormwater source control is the use of stormwater sources such as green areas, grasses and trees, buildings, etc. to absorb and abate rainwater runoff in a decentralized manner, with typical techniques such as greening on top of houses, infiltration-type green space construction, rainwater absorption gardens, permeable road construction, and permeable ditch $[23,53-55]$.

\subsection{Sponge City Construction in China}

The above-mentioned urban pluvial flooding governance strategies are mainly reflected in the construction of sponge cities in China [16,49-55]. In China, sponge city is a new generation of urban stormwater management concept, which means that cities can be as resilient as sponges in adapting to environmental changes and responding to natural disasters caused by stormwater, which can also be called "water-resilient cities" [53]. Sponge city construction follows the principles of ecological priority, combining natural ways and artificial measures to ensure the safety of urban drainage and pluvial flooding prevention, maximize the accumulation, infiltration and purification of stormwater in urban areas, and promote the use of stormwater resources and ecological environmental protection [47]. The goal of China's sponge city construction is to make $70 \%$ of urban rainfall be absorbed and utilized in situ. The timeline set by the Chinese government around this goal is for $80 \%$ of urban built-up areas to meet this requirement by 2030 [23]. To achieve this goal, the Chinese government has formulated relevant policies. Firstly, to prepares scientific planning and establishes a regional stormwater discharge management system. Secondly, the planning is to be implemented strictly. That is, sponge city construction will have requirements such as urban planning permission and project construction pre-conditions, in the construction plan review, construction permit, completion acceptance and other aspects of strict gate-keeping. Thirdly, to revise and improve the standards and norms related to the construction of sponge cities. Fourthly, to coordinate and promote the old and new urban sponge city construction. Fifthly, to promote sponge-type buildings and neighborhoods, sponge-type roads and squares, promote the construction of urban drainage and pluvial flooding prevention facilities and flood-prone point transformation, and the 
implementation of rain and sewage diversion. Sixthly, to promote the construction of parks and green spaces and natural ecological restoration. Seventhly, to encourage social capital to participate in sponge city investment, construction and operation management, and encourage technical enterprises to combine with financial capital and adopt general contracting to undertake relevant construction projects to bring overall benefits $[23,52]$. The Chinese government is promoting the construction of sponge cities through a number of measures [16,23].

\subsection{Implementation Opinions on Strengthening Urban Pluvial Flooding Governance Issued by the General Office of the State Council of China}

In April 2021, the General Office of the State Council of China issued a policy document on the implementation opinions on strengthening urban pluvial flooding governance [23]. The policy document points out that the Chinese government will systematically build urban drainage and pluvial flooding control engineering systems, improve the management level of urban drainage and pluvial flooding control work, and promote urban pluvial flooding control in a coordinated manner in the next 15 years [23]. In the construction of urban drainage and pluvial flooding control engineering system, the Chinese government will implement five major projects one after another until 2035, including the implementation of river and lake systems and ecological space management and restoration, the implementation of pipe network and pumping station construction and renovation, the implementation of drainage channel construction, the implementation of stormwater source reduction projects, and the implementation of pluvial flooding control and upgrading projects. In improving the management level of urban drainage and pluvial flooding control, five construction projects will be promoted, including strengthening daily maintenance, implementing pluvial flooding "joint drainage and joint adjustment", improving emergency management, strengthening professional team building, and strengthening the construction of intelligent platform.

The Chinese government will promote urban pluvial flooding governance in a coordinated manner through the above-mentioned efforts to achieve the following four goals. Firstly, by 2025, each city according to local conditions will basically form a "source of emission reduction, pipe network discharge, storage and drainage, over the standard emergency" urban drainage and pluvial flooding control engineering system, drainage and pluvial flooding control capacity will be significantly improved. Secondly, as an effective response to urban pluvial flooding control standards within the rainstorm, the old city can be drained in a timely manner after the rainstorm stops, the pluvial flooding control and drainage capacity of low-lying areas is greatly enhanced, the flood-prone waterlogging points that have historically seriously affected the order of production and life are completely eliminated, and the phenomenon of "urban sea-viewing" no longer occurs in the new city. Thirdly, under the rainstorm conditions that exceed the standard of urban pluvial flooding prevention and control, important municipal infrastructure such as urban lifeline projects do not lose their functions and basically guarantee the safe operation of the city. Fourthly, places with conditions to actively promote the construction of sponge cities. By 2035, the cities drainage and pluvial flooding control engineering system to further improve, drainage and pluvial flooding control capacity and the construction of sponge cities, resilient city requirements to better match the overall elimination of prevention and control standards within the rainstorm conditions of the urban pluvial flooding phenomenon [23].

\section{Fragmentation Dilemma in Urban Pluvial Flooding Governance in China \\ 4.1. The Connotation of Fragmentation in Urban Pluvial Flooding Governance}

Fragmentation in the administrative field refers to the lack of coordination among government departments and the difficulty of effective communication and cooperation, and the difficulty of different departments to work together to solve problems, resulting in the division of horizontal and vertical administrative functions in government agencies [36]. Fragmentation in pluvial flooding management specifically refers to the fragmentation 
of the administrative functions of various government departments in the city, such as water, urban construction, environmental protection, meteorology and other departments, resulting in the fragmentation of governance authority in each department, dull framework of authority and responsibility, lack of coordination and cooperation, in a state of fragmentation [16]. By studying the hierarchy and division of power functions in the Chinese bureaucracy, Lieberthal et al. introduced the concept of "Fragmented Authoritarianism". Incorporating this concept, this paper presents a fragmented characterization of the existing urban pluvial flooding governance in China from three dimensions [56]. The first dimension is the fragmentation of value integration in urban pluvial flooding governance, i.e., the conflict between management orders and service values in urban pluvial flooding governance [56]. The second dimension is the fragmentation of resources and power allocation in urban pluvial flooding governance, which is reflected in the lack of vertical top-level design and blurred horizontal departmental management boundary in urban pluvial flooding governance [56]. The third dimension is the fragmentation of policy formulation and implementation in urban pluvial flooding governance, which is concentrated in outdated urban pluvial flooding control standards as well as information barriers and information silos $[16,47,57,58]$. The fragmented features of the above three dimensions reflect the deep-seated causes in urban pluvial flooding governance in China from top to bottom, from the values of urban pluvial flooding governance to the distribution of powers of governance subjects to the policy-making and information platform dilemmas [54-56].

\subsection{Fragmentation of Value Integration}

The Chinese government has already started the corresponding governance work, which is mainly in the form of command-driven management, but there is not enough attention given to service-oriented drive [16]. With regard to management objectives, the government is confined to the quagmire of interests in carrying out its work, resulting in a distorted relationship between the government and the people, by which the public is no longer a real service object, but a mechanized management object [53]. It is impossible to fundamentally understand the needs of people by putting personal performance first when officials are in power [58]. In this context, problems such as urban pipeline congestion are particularly common, and they have not been effectively solved in the long-term development $[54,55]$. In terms of management constraints, the communication between governments at all levels and departments is more casual, and there is no standardized dialogue platform [48]. At the same time, there is no restriction of responsibility risk sharing system. Although the communication between different government departments is carried out, it is inefficient. Despite the introduction of relevant documents represented by the Flood Prevention Law, they mostly stay on the surface and do not go deeper into the substantive issues [27]. This kind of problem can be summarized into two aspects. On the one hand, the government work lacks standardized guidance, and all kinds of service behaviors have strong randomness [16]. On the other hand, the government departments have a weak sense of overall governance, most of them are limited to the "interest ontology". Additionally, their administrative actions are mainly based on their own interests, while ignoring the cooperation with the relevant departments. The official report of the Chinese government points out that the main contradiction in the current Chinese society has changed substantially into the contradiction between the people's growing need for a better life and the unbalanced and inadequate development [28]. In order to achieve fine governance in urban management, government services should not stay on the surface, but should focus on the pursuit of humanized management, and public services should be people-oriented [23]. Government services in China refer to the services provided by the government to the public such as weather forecasting, disaster warning, etc. These services can only be determined by Chinese government departments, because in China the law stipulates that only government agencies can provide these services, other social organizations and private organizations are prohibited from providing such services [24]. People's demand for high-quality services has gradually increased, but the phenomenon 
of "one-size-fits-all management" is still common today, and the contradiction between the two is becoming more and more obvious, which is one of the deep causes of the fragmentation problem highlighted in the current urban pluvial flooding governance [54].

\subsection{Fragmentation of Resources and Power Allocation}

Urban pluvial flooding governance is a complex and systematic work related to the construction and operation of urban pipe network, landscaping, greenery, etc. [45]. The smooth development of this work needs to be based on the cooperation of all departments. However, under the influence of the traditional bureaucracy, the current government's functional system is complex, and most of the institutions are set up on the basis of professional division of labor. It is difficult to make rational use of the whole resources of the government under the multi department division management pluvial flooding control system.

Firstly, the top-level design of urban pluvial flooding governance is not perfect, resulting in the relevant design planning and reality out of touch. In the vertical subordination, the management of water authorities at all levels are subject to the guidance of higher water affair departments, but also by the local government leadership, while the national planning of the Ministry of Water Resources and local water authorities are slightly more general in the circle of responsibilities. The lower water affair department is almost a replica of the higher water affair department, management and supervision of the same structure of the power to highlight the problem of things in the lower water department and power in the upper water department, the power and responsibility of the situation is disconnected. In addition, the distribution of urban pluvial governance affairs along the chain of command in the process of passing from the upper level to the lower level is prone to the misalignment problem.

Secondly, urban pluvial flooding governance lacks scientificity in the establishment of same administrative level departments, and there is a general problem of blurred boundaries of power and responsibility. In terms of the current urban pluvial flooding governance system, it mainly adopts a compartmentalized model of the administrative system, with the professional scope as the basis for the division of functions. The main reason for the problem of fragmentation of governance is the lack of coordination between professional departments and the lack of maturity of their coordination mechanisms. For example, when planning a drainage network, the urban decision makers do not make a comprehensive analysis of the feasibility of the scheme. The construction department only pays attention to the construction cost management, but does not do the corresponding operation and maintenance after the completion of construction. Likewise, the management considers more about the maintenance at the later stage and does not intervene enough in the preliminary planning and construction [16]. Such as flood warning and related diversion work, its corresponding service subjects differ, widely covering water, meteorology and other departments, this separate management mechanism is likely to lead to pipeline maintenance is not timely, daily supervision is not in place, rainstorm assessment is not accurate and many other problems. This is also a reflection of the blurred management boundaries of various departments, such as unclear responsibilities and powers are particularly evident.

In addition, there is no efficient communication mechanism between departments, such as joint ministerial meetings, which makes the work lack of connection and thus has a restrictive impact on drainage efficiency. If subsequent problems arise, because of unclear power and responsibility, it is easy to blame each other between departments, which is also a waste of public resources. Urban drainage is a typical watershed concept, and dividing the management area according to different urban areas will fragment the rainwater circulation process, which will lead to confusion of functions among different departments and intensify the fragmentation phenomenon of pluvial flooding governance. 


\subsection{Fragmentation of Policy Formulation and Implementation}

China's current urban flood control standards [16] are far behind the development of cities, and they cannot adapt to current urban development conditions, resulting in limitations in urban pluvial flooding governance. The outdated management technology is the most important reason for pluvial flooding in cities. Additionally, most cities only follow the old model in the anti-flooding work, and there are obvious limitations in analyzing the characteristics of pipe network flow, etc. On the level of planning timeframe, the city master plan is usually 20 years but, in practice, the service period of the pipe network often reaches more than 50 years [16], so the urban drainage network will undergo several revisions and adjustments of the city master plan, and the original set of drainage facilities often passively catch up with the actual needs of the changing reality, resulting in the disconnect between urban flood control standards and the real environment, thus losing its guiding significance.

In 1975, China promulgated the drainage system design standards for once in 0.33-2 years, experienced four revisions to 2011 to adjust to: once in 1-3 years in general areas, once in 3-5 years in important areas, compared with Europe and the United States and other developed cities and drainage pipe and flood control standards are still a small gap [16]. Additionally, in the traditional planning and design of drainage systems, the main focus is on the lower limit of urban flood control standards, and there is a lack of reasonable countermeasures for rainstorm exceeding the standards [23,47]. There is a lack of standardized guidance for urban flood control design, and even for drainage canals in the same area, the design standards for drainage networks, drainage channels, and flood pumping stations are not unified across departments, and the degree of interface between them is poor, which has led to fragmentation in the formulation and implementation of urban pluvial flooding governance policies [45].

The information on the drainage pipe network is incomplete, and the information barriers among various departments hinder the coordination in the process of urban pluvial flooding control. Due to the needs of urban planning and development, the expansion of the underground drainage pipe network is becoming more and more frequent. However, the underground drainage pipe network is a hidden project, which is often ignored after the landfill operation. Compared with the above ground buildings, the daily management of underground pipelines in most cities of China is not enough, and there is no effective supervision and management system. The relevant urban management departments and project construction departments do not have a strong sense of standardization, for example, the underground pipeline construction does not carry out the completion survey as required, or the drawings and data of the completion survey are not submitted to the management department as required. At present, the data of underground pipe network in most cities of China are incomplete [53]. About 70\% of the cities in China do not have the basic archives of the underground pipe network, and the vast majority of cities in China do not have a comprehensive underground pipeline comprehensive map or database [16].

Due to the complexity of the organization of urban underground drainage pipeline, and the continuous expansion work, the information of underground pipeline diameter and length is distributed in various government agencies, and there is a lack of a unified management information platform. Moreover, most of the existing underground pipe network data are recorded and saved in traditional forms such as drawings and charts, which lack of scientific and technological information management means, unclear positioning of underground pipeline, incomplete and inaccurate basic data of pipeline. Even some government departments regard the obtained data as private property, which increases the degree of data information blockade, making it difficult for the data information of water related management to form an organic whole, and there are information barriers among various departments. 


\section{Holistic Governance Strategy for Fragmentation Dilemma of Urban Pluvial Flooding Governance in China}

Holistic governance emerged in Britain in the late 1990s, which is a strategic response to fragmentation in the process of closed governance and competitive governance [36]. The core of holistic governance is to advocate the coordination of the government's vertical and horizontal structure and power, so as to realize the transformation from decentralization to centralization, from departments to the whole, and from fragmentation to integration. Holistic governance tries to form a multiple partnership of administrative subjects, emphasizes the functional complementarity and mutual embeddedness among multiple governance subjects, helps government agencies to reengineer and innovate with results and purposes as the center, and realizes the integrated operation of government and the intensive supply of public services. The first problem to be solved by holistic governance theory is fragmentation. Its theoretical core is coordination and integration, which emphasizes the government's own construction, people-oriented thought, reshapes the value and sense of responsibility of public administration, takes the needs of citizens as the starting point, establishes the result oriented consciousness, continuously optimizes the government's work process, and provides seamless public services.

At present, holistic governance has been regarded as an effective measure to solve the problem of fragmentation. In the aspect of urban pluvial flooding governance, the effective embedding of holistic governance in the government can help to alleviate the horizontal departments' vigilance against "invasion behavior", realize the cooperation and mutual assistance of governance subjects, and boost the long-term governance of urban pluvial flooding problem. Therefore, the holistic governance of urban pluvial flooding is not only a technical issue, but also an innovation and remodeling of the traditional governance model.

\section{Realization Path of Holistic Governance Model for Urban Pluvial Flooding Governance Fragmentation Dilemma}

Based on the above analysis of the fragmentation of urban pluvial flooding governance, we know that the fragmentation of the governance model is mainly influenced by both the fragmentation of urban pluvial flooding governance subjects and the fragmentation of the governance mechanism. Therefore, in order to break through the fragmentation of urban pluvial flooding management, the government should take the theory of holistic governance as the core, focus on establishing a coordination and cooperation mechanism, and use information technology as a breakthrough to create a mature model of holistic urban pluvial flooding governance. This paper proposes the following four realization paths and countermeasures.

\subsection{Forming a Governance Network with the Participation of Multiple Subjects}

The key to the holistic governance of urban pluvial flooding lies in the transformation of the governance system, which focuses on the formation of a multifaceted dynamic governance structure with compatibility, and the dynamic adjustment of governance power and resources within organizations, formal and informal organizations, and between government and society, so as to improve and enrich the governance subjects on the one hand, and optimize the governance relationship and governance path on the other. Enhancing the quality of public services and diversifying governance subjects are the key ways to practice holistic governance theory. The most basic thing is that government departments need to break the shackles of the old single model, not just listen to the words of the government body, to create an efficient service-oriented governance mechanism. In the new framework of multi-disciplinary governance of urban pluvial flooding, the government further plays the role of an organizer and coordinator, and actively eliminates the obstacles in the governance network, so that each governance subject can express its own views. At the same time, it is necessary to break the shackles of internal closure of government organizations, deepen the cooperation mechanism of government departments at all levels, and promote and deepen the coordination and cooperation among different departments. 
In terms of social groups, under the new institutional environment, the government should actively encourage citizens to contribute to urban water flooding governance, treating them as participants rather than passive receivers and treating urban water flooding governance as a common matter for all. The government, society and the market should form a close connection mechanism, and strive to seamlessly integrate the work of each other [38], eventually forming an effective model of urban pluvial flooding governance.

\subsection{Promote Organizational Restructuring and Reform to Create a Synergistic Operation Mechanism}

In the framework of functional and hierarchical division, the heterogeneity of governmental organizations and departments is caused by the overly specialized division of labor, and the different roles and responsibilities of institutions and their interests, resulting in the deviation of governance mechanisms from governance objectives. Holistic governance theory advocates process reengineering of the organization, integration and innovation of departments with similar functions, and clarification of vertical and horizontal communication paths between departments to fundamentally solve the problem of blurred boundaries of management functions.

Firstly, it is important toestablish diverse channels of consultation and create an effective mechanism for dialogue. Specifically, the Water Affairs Bureau in the city needs to be the leader, fully mobilize the departments responsible for organizing joint meetings to exchange and discuss the management of urban flooding, brainstorming. At the same time, the emergency management office should pay great attention to the daily supervision and management of emergency, clarify the responsibilities and rights within the organization, pay attention to the interface between the competences of relevant departments, and create a closed supervision loop.

Secondly, it is important to form a scientific benefit-sharing mechanism. The division and adjustment of responsibilities cannot cure the fragmentation of urban pluvial flooding governance system, but the common interests of all parties are the core driving force of governance actions. Therefore, the interests of various departments should be weighed and analyzed, and a reasonable benefit and risk sharing mechanism should be established, such as setting up a cross-border urban pluvial flooding governance fund to share the cost reasonably based on the size of the governance responsibilities and roles.

At the beginning of the transformation of urban stormwater flooding governance, the policy environment will not be very mature in all aspects. Therefore, the government should give full play to its role as an exemplary model. Drawing on the experience of the establishment of the "New York City Panel on Climate Change" [59], the organization of urban pluvial flooding governance transition should also be sustained and regularized. Additionally, an urban pluvial flooding governance office can be created in a targeted manner, with the participation of representatives from various parties including government, market, and public to enhance the ability to make comprehensive decisions and to propose feasible action plans for the actual situation in the subsequent emergency response, so that measures can be taken to address the risk of urban pluvial flooding.

\subsection{Forming a Data Sharing Network Platform and Creating a Unified Governance Information Center}

The smooth implementation of urban pluvial flooding governance needs to be based on the acquisition of comprehensive and correct information for decision making, therefore, the first-hand information of each department should be summarized continuously to avoid the problem of inefficient decision making and resource allocation due to information asymmetry. In terms of the current vertical local management in China, the actual disaster summary and reporting process at the governmental level is easily influenced by human factors, resulting in distorted information and delayed reporting, while there is no effective information transmission path between horizontal departments.

Technology is not neutral, and in some cases it is influenced by social and political factors in order to achieve different goals. The holistic urban pluvial flooding gover- 
nance model advocates the use of advanced information technology to establish crossdepartmental and cross-regional information exchange and sharing mechanisms, and promote the sharing and integration of information among different levels and departments to provide data support for urban pluvial flooding governance decisions. Typical technologies include intelligent cloud platforms and full-process dynamic network platforms, which can collect a wide range of data related to monitoring and forecasting, disaster resilience and vulnerability for reference by decision makers.

In order to establish a smooth information flow path, the first step is to realize the openness and sharing of data. There are two main ways. The first way is to link to government portals, public data for the general public, and portable platforms such as APPs launched by companies to target weather conditions. Another way is to set up a specialized database within the organization, with internal networking for more private or IP-related data. Public databases and specialized databases will constitute the core data sources of the basic data platform. On the basis of the data support for the establishment of urban pluvial management linkage command platform, fully involved in the city and even individual neighborhoods. The first step is to summarize the relevant data from the city, district, and even the street, and then integrate the data into the information storage center. In the second step, the information is collected dynamically, screened and evaluated by means of a unique information query language, and aggregated by category. In the third step, the collected information is identified, disposed and transferred to form an integrated platform of urban flood monitoring, early warning and management. Among all the data system levels, the urban storm and flood control linkage command platform is the highest level, which can effectively integrate all kinds of internal and external data and provide easy entrance for other basic data to achieve the effect of "vertical to the end and horizontal to the edge". According to the above, the information platform of urban pluvial flooding governance can meet the innovative governance needs at different levels: firstly, it breaks the information silo and provides a way for data flow; secondly, it realizes real-time update of data and provides guidance for decision making; thirdly, it enhances the efficiency of execution linkage and action response, and has reference significance for the governance of other urban problems.

\subsection{Establishing Monitoring, Administrative Performance, and Legal System}

The holistic governance of urban pluvial flooding is a typical collective action, but in collective action, rational, self-interested individuals will not act to achieve the common good. The existence of clear rules for urban pluvial flooding governance ultimately benefits all members of the organization and can even benefit society as a whole. Accordingly, the implementation of holistic governance of urban pluvial flooding is also dependent on the construction of relevant systems.

Firstly, it is important to establish a monitoring system for the holistic governance of urban pluvial flooding. The National Flood Control and Drought Relief Command is in the leading position and needs to play a leading role in communicating with various departments to set the goals of urban pluvial flood control, and establish an accountability mechanism with clear power and responsibility beforehand and accountability afterwards. The holistic governance of urban pluvial flooding is a highly complex task, which involves not only the supervision of the upper level government and the mutual supervision of the horizontal departments, but also the supervision of many subjects such as the press and the public, and the integration of various forms of supervision and supervision systems to create a perfect supervision system.

Secondly, a mature assessment and evaluation and reward system is introduced with the basic principle of holistic governance of urban pluvial flooding. In the early stage of urban pluvial flooding governance transition, a top-down administrative performance assessment and incentive model should be implemented to provide motivation for active cooperation of actors at all levels. Therefore, the current Gross National Product-centered performance appraisal system should be changed to fully incorporate indicators related 
to urban pluvial flooding governance [23]. In the holistic governance of urban pluvial flooding, positive incentives and negative penalties should be combined, under the continuous influence of the positive incentive system, to deepen the cooperation mechanism of the governance bodies; timely correction of problems and penalties, to prevent people from floating in the process of governance. In particular, punitive measures will strengthen urban flood managers to pay attention to the implementation of various institutional measures, and will also involve various stakeholders in all aspects of urban pluvial flooding governance $[16,57,58]$.

Thirdly, it is important to create a healthy legal system, to provide a good legal environment for the development of urban pluvial flooding governance work. Specifically, the most basic thing is to deepen the legal system related to urban pluvial flooding governance, and take the high-ranking law as a breakthrough to implement the governance process. In addition, it is necessary to update urban planning standards in a timely manner, taking into account the real environment and actual needs, and to reasonably delineate the scope of application of urban planning standards, so as to better realize the articulation of urban planning and laws and regulations.

\section{Discussions}

Urban pluvial flooding in China has become one of the major challenges for sustainable development, and how to effectively manage urban pluvial flooding is a development issue that urban policy makers need to face head-on [16]. The holistic governance of urban pluvial flooding in China has undergone several changes, from the initial emphasis on the construction of drainage and flood control facilities, to the implementation of sponge measures such as infiltration, retention, storage, purification, utilization and drainage, to the comprehensive management and systemic management model, i.e., basinwide, city-wide, process-wide, society-wide, element-wide, all-round, phased and focused multi-dimensional management [23]. The holistic governance of urban pluvial flooding emphasizes an integrated and systematic approach to solving the problem of urban pluvial flooding, and also reflects a dynamic, holistic, perpetual and thinking approach, with clear governance objectives and governance measures that require technology empowerment, increased investment, departmental synergy, localization, and a comprehensive system response to a city.

At the same time, we must recognize that the risk of urban flooding is also evolving [ $48,49,52]$. On the one hand, as China's urbanization continues to advance, population and wealth continue to cluster in cities, and the population and wealth exposed to flooding risks are increasing accordingly $[16,23,39]$. On the other hand, global changes and climate warming have increased the flood-prone urban space and the possibility of flooding [46]. Additionally, the widespread application of new materials, new energy and new technologies, and the emergence of new industries, new business models and new fields make the urban operation system increasingly complex and the types of risks are increasing. Urban flooding will not only cause casualties and economic losses, but also trigger derivative and secondary disasters. Therefore, how are we to really change the dilemma of "urban sea-viewing"? Firstly, we must correct the input understanding. To change the misconception that there is no return on investment in disaster prevention, recognize the importance and urgency of the work of managing urban pluvial flooding. Reducing disaster losses is necessary to increase social wealth [29]. Urban pluvial flooding governance is a matter of people's lives and property security, is not only a project relevant to people's livelihood, but also a major development project. Secondly, we must strengthen the application of research. Generally speaking, the deeper the waterlogging, the more serious the disaster. Since the geographical conditions, development stages, and social culture vary widely across China, it is difficult to characterize this law with uniform parameters, yet it is indispensable in the risk assessment of flooding in specific cities. Unfortunately, there is little case study accumulation in this area. Thirdly, we must recognize the importance of risk assessment. The risk assessment of urban pluvial flooding is the basic work of urban pluvial flooding 
governance, and it is also a relatively strong technical work. We should make full use of the information and results of the first national comprehensive risk census of natural disasters being carried out in China, and use remote sensing, and artificial intelligence technologies to systematically and deeply carry out the risk assessment of urban pluvial flooding based on large scale base maps with the help of expert team strength. Fourthly, we must strengthen publicity and education. We should use online and offline, physical and virtual, traditional media and new media and other ways and means to promote the significance, importance and methods of urban pluvial flooding prevention and control, and comprehensively enhance the awareness of urban pluvial flood risk prevention.

\section{Summary}

This paper has discussed the causes of urban pluvial flooding in China and the current situation of its governance, especially the construction of sponge cities. Then, this paper analyzes the fragmentation dilemma faced by urban pluvial flooding in China, including the fragmentation of value integration, the fragmentation of resource allocation and power distribution, and the fragmentation of policy formulation and implementation. Finally, the holistic management strategies and paths for urban pluvial flooding in China are elaborated, including forming a governance network with the participation of multiple subjects, promote organizational restructuring and reform to create a synergistic operation mechanism, forming a data sharing network platform and creating a unified governance information center, establishing monitoring, administrative performance, and legal system.

Author Contributions: Conceptualization, F.K., Y.W. and S.S.; methodology, F.K.; software, Y.W. and S.S.; validation, F.K., Y.W. and S.S.; writing—original draft preparation, F.K., Y.W. and S.S.; writingreview and editing, F.K., Y.W. and S.S.; supervision, Y.W. and S.S.; project administration, S.S.; funding acquisition, S.S. All authors have read and agreed to the published version of the manuscript.

Funding: This research was funded by the National Key Research and Development Program of China, grant number 2018YFE0109600, Chinese Universities Scientific Fund, grant number 2021TC062, the National Natural Science Foundation of China, grant number 41701103, 41775078, 41801064 and 71790611, MOST Special Fund for the Fourth National Assessment Report on Climate Change, and the Beijing Social Science Foundation Project, grant number 19JDGLA008.

Institutional Review Board Statement: Not applicable.

Informed Consent Statement: Not applicable.

Data Availability Statement: No new data were created or analyzed in this study. Data sharing is not applicable to this article.

Conflicts of Interest: The author declares that no conflicts of interest exists.

\section{References}

1. IPCC Climate Change. Contribution of Working Groups I, II and III to the Fifth Assessment Report of the Intergovernmental Panel on Climate Change; Cambridge University Press: Cambridge/London, UK, 2014.

2. IPCC SR1.5. Global Warming of $1.5^{\circ} \mathrm{C}$; Cambridge University Press: Cambridge, UK, 2018.

3. Field, C.B.; Barros, V.; Stocker, T.F.; Qin, D.; Dokken, D.J.; Ebi, K.L.; Mastrandrea, M.D.; Mach, K.J.; Plattner, G.-K.; Allen, S.K.; et al. Climate Change. In Managing the Risks of Extreme Events and Disasters to Advance Climate Change Adaptation; IPCC: Cambridge, UK; Cambridge University Press: London, UK, 2012.

4. United Nations International Strategy for Disaster Reduction (UNISDR). Global Assessment Report on Disaster Risk Reduction; United Nations: New York, NY, USA, 2019.

5. Dai, Y.; Jiang, J.; Gu, X.; Zhao, Y.; Ni, F. Sustainable Urban Street Comprising Permeable Pavement and Bioretention Facilities: A Practice. Sustainability 2020, 12, 8288. [CrossRef]

6. Hou, J.; Du, Y. Spatial simulation of rainstorm waterlogging based on a water accumulation diffusion algorithm. Geomatics Nat. Hazards Risk 2020, 11, 71-87. [CrossRef]

7. Kong, F.; Sun, S. Better Understanding Insurance Mechanism in Dealing with Climate Change Risk, with Special Reference to China. Int. J. Environ. Res. Public Health 2021, 18, 2996. [CrossRef] [PubMed]

8. Ishimatsu, K.; Ito, K.; Mitani, Y.; Tanaka, Y.; Sugahara, T.; Naka, Y. Use of rain gardens for stormwater management in urban design and planning. Landsc. Ecol. Eng. 2017, 13, 205-212. [CrossRef] 
9. Allan, R.P.; Soden, B. Atmospheric Warming and the Amplification of Precipitation Extremes. Science 2008, 321, 1481-1484. [CrossRef] [PubMed]

10. Zhang, X.; Hu, M.; Chen, G.; Xu, Y. Urban Rainwater Utilization and its Role in Mitigating Urban Waterlogging Problems-A Case Study in Nanjing, China. Water Resour. Manag. 2012, 26, 3757-3766. [CrossRef]

11. Saksena, S.; Dey, S.; Merwade, V.; Singhofen, P.J. A Computationally Efficient and Physically Based Approach for Urban Flood Modeling Using a Flexible Spatiotemporal Structure. Water Resour. Res. 2020, 56, e2019WR025769. [CrossRef]

12. Liu, J.; Shao, W.; Xiang, C.; Mei, C.; Li, Z. Uncertainties of urban flood modeling: Influence of parameters for different underlying surfaces. Environ. Res. 2020, 182, 108929. [CrossRef] [PubMed]

13. State Council of China. Review of the Authoritative Release of the Joint Prevention and Control Mechanism of the State Council. Available online: http:/ / sousuo.gov.cn/column/49276/0.htm (accessed on 25 March 2021).

14. Shi, P.; Jeager, C.; Ye, Q. Integrated Risk Governance; Springer: Berlin/Heidelberg, Germany, 2013.

15. Kong, F. Long and short duration heavy rainfall spatio-temporal patterns change and its contribution to total heavy rainfall in China. In Proceedings of the IOP Conference Series: Earth and Environmental Science; IOP Publishing: Bristol, UK, 2019; Volume 310, p. 52006.

16. Kong, F.; Sun, S.; Lei, T. Understanding China's Urban Rainstorm Waterlogging and Its Potential Governance. Water 2021, $13,891$. [CrossRef]

17. Liu, F.; Liu, X.; Xu, T.; Yang, G.; Zhao, Y. Driving Factors and Risk Assessment of Rainstorm Waterlogging in Urban Agglomeration Areas: A Case Study of the Guangdong-Hong Kong-Macao Greater Bay Area, China. Water 2021, 13, 770. [CrossRef]

18. Su, M.; Zheng, Y.; Hao, Y.; Chen, Q.; Chen, S.; Chen, Z.; Xie, H. The influence of landscape pattern on the risk of urban wa-ter-logging and flood disaster. Ecol. Indic. 2018, 92, 133-140. [CrossRef]

19. McGranahan, G.; Balk, D.; Anderson, B. The rising tide: Assessing the risks of climate change and human settlements in low elevation coastal zones. Environ. Urban. 2007, 19, 17-37. [CrossRef]

20. Sun, S.; Zhai, J.; Li, Y.; Huang, D.; Wang, G. Urban waterlogging risk assessment in well-developed region of Eastern China. Phys. Chem. Earth Parts A/B/C 2020, 115, 102824. [CrossRef]

21. Yang, B.; Lee, D. Planning Strategy for the Reduction of Runoff Using Urban Green Space. Sustainability 2021, 13, 2238. [CrossRef]

22. Ma, M.; Wang, H.; Jia, P.; Liu, R.; Hong, Z.; Labriola, L.G.; Hong, Y.; Miao, L. Investigation of inducements and defenses of flash floods and urban waterlogging in Fuzhou, China, from 1950 to 2010. Nat. Hazards 2018, 91, 803-818. [CrossRef]

23. The General Office of the State Council of China. Implementation Opinions on Strengthening Urban Pluvial Flooding Governance. Available online: http:/ / www.gov.cn/zhengce/content/2021-04/25/content_5601954.htm (accessed on 18 June 2021).

24. Ministry of Emergency Management of the People's Republic of China. Public Affairs: Public Emergencies. Available online: http:/ / www.mem.gov.cn/gk/jytabljggk/ (accessed on 18 June 2021).

25. Central People's Government of the People's Republic of China. 2021 Government Work Report. Available online: http: / / www.gov.cn/guowuyuan/zfgzbg.htm (accessed on 18 June 2021).

26. Cheng, X.T. Changes of Flood Control Situations and Adjustments of Flood Management Strategies in China. Water Int. 2005, 30, 108-113. [CrossRef]

27. Cheng, X.T. Recent progress in flood management in China. Irrig. Drain. 2006, 55, 75-82.

28. Wu, Z.; Shen, Y.; Wang, H. Assessing Urban Areas' Vulnerability to Flood Disaster Based on Text Data: A Case Study in Zhengzhou City. Sustainability 2019, 11, 4548. [CrossRef]

29. Lo, A.Y.; Xu, B.; Chan, F.K.S.; Su, R. Household economic resilience to catastrophic rainstorms and flooding in a chinese megacity. Geogr. Res. 2016, 54, 406-419. [CrossRef]

30. Merz, B.; Kreibich, H.; Lall, U. Multi-variate flood damage assessment: A tree-based data-mining approach. Nat. Hazards Earth Syst. Sci. 2013, 13, 53-64. [CrossRef]

31. Lutz, J.; Grinde, L.; Dyrrdal, A.V. Estimating Rainfall Design Values for the City of Oslo, Norway-Comparison of Methods and Quantification of Uncertainty. Water 2020, 12, 1735. [CrossRef]

32. Gironás, J.; Roesner, L.A.; Rossman, L.A.; Davis, J. A new applications manual for the Storm Water Management Model (SWMM). Environ. Model. Softw. 2010, 25, 813-814. [CrossRef]

33. Tian, X.; Veldhuis, M.-C.T.; Schleiss, M.; Bouwens, C.; van de Giesen, N. Critical rainfall thresholds for urban pluvial flooding inferred from citizen observations. Sci. Total Environ. 2019, 689, 258-268. [CrossRef] [PubMed]

34. Shi, P.; Xu, W.; Wang, J. Natural Disasters in China; Springer: Berlin/Heidelberg, Germany, 2016.

35. Trenberth, K. Changes in precipitation with climate change. Clim. Res. 2011, 47, 123-138. [CrossRef]

36. Konapala, G.; Mishra, A.K.; Wada, Y.; Mann, M.E. Climate change will affect global water availability through compounding changes in seasonal precipitation and evaporation. Nat. Commun. 2020, 11, 1-10. [CrossRef] [PubMed]

37. Schuster, Z.T.; Potter, K.W.; Liebl, D.S. Assessing the Effects of Climate Change on Precipitation and Flood Damage in Wisconsin. J. Hydrol. Eng. 2012, 17, 888-894. [CrossRef]

38. Mei, C.; Liu, J.; Wang, H.; Li, Z.; Yang, Z.; Shao, W.; Ding, X.; Weng, B.; Yu, Y.; Yan, D. Urban flood inundation and damage assessment based on numerical simulations of design rainstorms with different characteristics. Sci. China Ser. E Technol. Sci. 2020, 63, 2292-2304. [CrossRef]

39. Chen, L.; Jiang, R.; Xiang, W.-N. Surface Heat Island in Shanghai and Its Relationship with Urban Development from 1989 to 2013. Adv. Meteorol. 2015, 2016, 1-15. [CrossRef] 
40. Zheng, Z.; Gao, J.; Ma, Z.; Wang, Z.; Yang, X.; Luo, X.; Jacquet, T.; Fu, G. Urban flooding in China: Main causes and policy recommendations. Hydrol. Process. 2015, 30, 1149-1152. [CrossRef]

41. Semadeni-Davies, A.; Hernebring, C.; Svensson, G.; Gustafsson, L.-G. The impacts of climate change and urbanisation on drainage in Helsingborg, Sweden: Suburban stormwater. J. Hydrol. 2008, 350, 114-125. [CrossRef]

42. Semadeni-Davies, A.; Hernebring, C.; Svensson, G.; Gustafsson, L.-G. The impacts of climate change and urbanisation on drainage in Helsingborg, Sweden: Combined sewer system. J. Hydrol. 2008, 350, 100-113. [CrossRef]

43. Arosio, M.; Martina, M.L.V.; Creaco, E.; Figueiredo, R. Indirect Impact Assessment of Pluvial Flooding in Urban Areas Using a Graph-Based Approach: The Mexico City Case Study. Water 2020, 12, 1753. [CrossRef]

44. Kuruppu, U.; Rahman, A.; Rahman, M.A. Permeable pavement as a stormwater best management practice: A review and discussion. Environ. Earth Sci. 2019, 78, 327. [CrossRef]

45. Fratini, C.; Geldof, G.; Kluck, J.; Mikkelsen, P.S. Three Points Approach (3PA) for urban flood risk management: A tool to support climate change adaptation through transdisciplinarity and multifunctionality. Urban Water J. 2012, 9, 317-331. [CrossRef]

46. Sörensen, J.; Persson, A.; Sternudd, C.; Aspegren, H.; Nilsson, J.; Nordström, J.; Jönsson, K.; Mottaghi, M.; Becker, P.; Pilesjö, P.; et al. Re-Thinking Urban Flood Management-Time for a Regime Shift. Water 2016, 8, 332. [CrossRef]

47. Wong, T.H.F.; Brown, R.R. The water sensitive city: Principles for practice. Water Sci. Technol. 2009, 60, 673-682. [CrossRef]

48. Mertha, A. “Fragmented Authoritarianism 2.0": Political Pluralization in the Chinese Policy Process. China Q. 2009, 200, 995-1012. [CrossRef]

49. Zevenbergen, C.; Fu, D.; Pathirana, A. Sponge Cities: Emerging Approaches, Challenges and Opportunities; MDPI: Basel, Switzerland, 2018; ISBN 9783038972730.

50. Liao, K.-H. A Theory on Urban Resilience to Floods-A Basis for Alternative Planning Practices. Ecol. Soc. 2012, 17, 48. [CrossRef]

51. Qiao, X.-J.; Liao, K.-H.; Randrup, T.B. Sustainable stormwater management: A qualitative case study of the Sponge Cities initiative in China. Sustain. Cities Soc. 2020, 53, 101963. [CrossRef]

52. Huang, G. A Comparative Study on Flood Management in China and Japan. Water 2014, 6, 2821-2829. [CrossRef]

53. Dai, L.; Van Rijswick, H.F.M.W.; Driessen, P.P.J.; Keessen, A.M. Governance of the Sponge City Programme in China with Wuhan as a case study. Int. J. Water Resour. Dev. 2018, 34, 578-596. [CrossRef]

54. Jiang, Y.; Zevenbergen, C.; Fu, D. Understanding the challenges for the governance of China's "sponge cities" initiative to sustainably manage urban stormwater and flooding. Nat. Hazards 2017, 89, 521-529. [CrossRef]

55. Jiang, Y.; Zevenbergen, C.; Ma, Y. Urban pluvial flooding and stormwater management: A contemporary review of China's challenges and "sponge cities" strategy. Environ. Sci. Pol. 2018, 80, 132-143. [CrossRef]

56. Lieberthal, K.G.; David, M. Bureaucracy, Politics and Decision-Making in Post-Mao China; University of California Press: Berkeley, CA, USA, 1992.

57. Lv, X.L. Managing Uncertainty in Crisis: Exploring the Impact of Institutionalization on Organizational Sense-Making; Springer: Berlin/Heidelberg, Germany, 2017.

58. Li, M. Study on Raising Social Fund to Redistribute Disaster Risk with Lottery and Insurance. Ph.D. Thesis, Beijing Normal University, Beijing, China, 2016. (In Chinese)

59. Mayor's Office of Climate Resiliency of New York City. New York City Panel on Climate Change. Available online: https: / / www1.nyc.gov/site/orr/challenges / nyc-panel-on-climate-change.page (accessed on 18 June 2021). 